\title{
PERANAN PERGURUAN TINGGI DALAM PENINGKATAN KEPEDULIAN SOSIAL MAHASISWA MELALUI PELATIHAN KEWIRAUSAHAAN SOSIAL
}

\author{
Dian Rustyawati \\ Program Studi PAI, Fakultas Tarbiyah, IAINU Tuban. \\ Email : awardeean@gmail.com \\ Akhmad Zaini \\ Program Studi PAI, Fakultas Tarbiyah, IAINU Tuban. \\ Email : akhmadzaini@stitmatuban.ac.id
}

\begin{abstract}
Abstrak
Perguruan tinggi sebagai wadah belajar bagi mahasiswa memiliki peranan besar dalam membentuk sumber daya manusia mahasiswanya supaya menjadi pribadi yang tangguh. Mereka akan tumbuh sebagai pribadi yang memiliki empati tinggi, mengutamakan proses, menghargai orang lain, peduli, dan solutif. Oleh karena itu, perguruan tinggi bisa melakukan peningkatan kapabilitas mahasiswanya melalui pelatihan-pelatihan, salah satunya pelatihan kewirausahaan sosial. Dalam kewirausahaan sosial, mahasiswa akan belajar tentang bisnis sosial yang dekat dengan masyarakat. Diharapkan dengan mengembangkan bisnis sosial ini bisa menjadi solusi permasalahan yang ada di masyarakat. Peningkatan kepedulian sosial mahasiswa erat kaitannya dengan dampak yang diberikan. Perguruan tinggi diharapkan mampu menghasilkan impact entrepreneur yang mampu memiliki peranan dalam menyelesaikan permasalahan di masyarakat. Dengan mengikuti pelatihan kewirausahaan diharapkan mahasiswa bisa memiliki keberanian memulai usaha, mampu mencari pembeda dan value prepotition dari bisnisnya, melihat potensi, mengadopsi inovasi, dan pada akhirnya bisa mereplikasi keterampilan untuk diajarkan pada orang-orang di sekitarnya sehingga bisa menebar manfaat untuk lebih banyak orang lainnya.
\end{abstract}

Kata Kunci: peranan, perguruan tinggi, pelatihan, kewirausahaan, sosial.

\section{PENDAHULUAN}

Perguruan tinggi memiliki peran dan tanggung jawab sosial yang besar terhadap proses pendidikan mahasiswanya. Proses pendidikan ini tidak hanya mencakup keilmuan, tetapi juga mengasah soft skill dan hard skill. Selain itu juga, perguruan tinggi harus mampu menyiapkan para lulusannya untuk bisa memiliki peran dalam masyarakat setelah mereka lulus nantinya. Jika mampu mewujudkan hal ini, perguruan tinggi akan mendapat kepercayaan dari masyarakat.

Perguruan tinggi merupakan pendidikan tingkat lanjut setelah sekolah menengah. Dalam perguruan tinggi, mahasiswa dididik untuk mampu menjadi pribadi yang memiliki kemampuan akademis dan keahlian yang membuatnya menjadi seorang profesional yang mampu menerapkan, mengembangkan, dan melakukan inovasi di bidangnya sehingga bisa memberikan dampak positif bagi masyarakat.

Tanggung jawab sosial perguruan tinggi ini diwujudkan dalam tridharma perguruan tinggi, yaitu meliputi pendidikan, penelitian, dan pengabdian. Dalam pelaksanaannya, perguruan tinggi bisa 
menyisipkan nilai-nilai entrepreneurship ke dalam proses pembelajarannya. Di luar perkuliahan, perguruan tinggi bisa menyelenggarakan pelatihan kewirausahaan untuk memberikan bekal keahlian pada mahasiswa supaya bisa mendirikan lapangan usaha dan membuka lapangan pekerjaan sehingga bisa memberikan dampak sosial pada masyarakat.

Dalam prosesnya, perguruan tinggi bisa membangun ekosistem wirausaha dengan mendirikan entittas kewirausahaan bagi mahasiswa sebagai model pendampingan kewirausahaan pemula. Kegiatan entitas ini diawalmi dengan aktivasi komunikasi kreatif yang diposisikan sebagai media pembelajaran secara berkelanjutan (Purnomo,2017:69). Outcome yang diharapkan, mahasiswa mampu memiliki kecakapan dalam pemberdayaan lingkungan di sekitarnya dan memberikan dampak sosial bagi peningkatan taraf hidup masyarakat.

Selain itu, penting untuk dibentuk karakter yang kuat untuk mahasiswa, supaya mereka mampu menghadapi kendala yang dihadapi. Karakter dikembangkan melalui tahap pengetahuan (knowing), pelaksanaan (acting), dan kebiasaan (habit). Karakter tidak terbatas pada pengetahuan saja. Seseorang yang memiliki pengetahuan kebaikan belum tentu mampu bertindak sesuai dengan pengetahuannya, jika tidak terlatih (menjadi kebiasaan) untuk melakukan kebaikan tersebut. Karakter juga menjangkau wilayah emosi dan kebiasaan diri. Dengan demikian diperlukan tiga komponen karakter yang baik (components of good character) yaitu moral knowing (pengetahuan tentang moral), moral feeling atau perasaan (penguatan emosi) tentang moral, dan moral action atau perbuatan bermoral (Taufik, 2019:6).

Untuk mewujudkan outcome yang diharapkan, perguruan tinggi bisa mengadakan pelatihanpelatihan kewirausahaan dengan menggunakan model pembelajaran yang berfokus pada pembentukan karakter, etika, jiwa kewirausahaan, kepedulian, pengembangan kemampuan berkomunikasi, mengasah keterampilan menganalisa, dan lainnya.

Penyusunan artikel ini bertujuan untuk mengetahui sejauh mana peranan yang bisa diambil oleh perguruan tinggi dalam meningkatkan kepedulian mahasiswa pada lingkungan sekitarnya melalui pelatihan kewirausahaan sosial.

\section{A. Peranan Perguruan Tinggi}

Perguruan tinggi memiliki banyak peran dalam banyak bidang. Dalam hal yang berkaitan dengan Tri Dharma Perguruan Tinggi adalah memberikan jalan atau fasilitas kepada pelaku yakni dosen dan mahasiswa untuk melakukan pendidikan, penelitian, dan pengabdian. Tugas perguruan tinggi yang terumus dalam "Tridharma" perguruan tinggi, yaitu pendidikan, penelitian, dan pengabdian kepada masyarakat merupakan jalur paling strategis dalam pembinaan dan pengembangan nilai-nilai kewirausahaan yang dapat menjangkau seluruh lapisan masyarakat. 
Adapun faktor-faktor pendukung pengembangan kewirausahaan dalam lingkungan mahasiswa adalah sebagai berikut (Purnomo,2020:20).

1) Pemberian pengarahan yang logis, realistis, dan sistematis dari dosen kepada mahasiswa.

2) Sebagian besar dosen menjadi pengusaha.

3) Pengemasan materi yang menarik dalam bidang kewirausahaan yang diberikan kepada mahasiswa di kelas atau pun saat praktek.

4) Pemberian penghargaan kepada mahasiswa wirausaha, sehingga dapat menjaga semangat wirausaha mahasiswa,

5) Selalu memberikan materi terbarukan mengenai kewirausahaan dan isu-isu nasional bahkan internasional mengenai kewirausahaan.

\section{B. Kewirausahaan Sosial}

Social Entrepreneurship sebagai suatu organisasi yang memiliki unsur Entrepreneurship menunjukkan kemampuan menciptakan upaya-upaya baru untuk menyediakan segala kebutuhan sosial suatu komunitas. Organisasi Kewirausahaan Sosial merupakan organisasi yang berada pada sektor kerewalanan dengan misi meningkatkan kesejahteraan maupun upaya pemberdayaan masyarakat (Adipringandari,2014:23).

\section{Kriteria Kewirausahaan Sosial}

Ada empat kriteria dari socio entrepreneurship yaitu nilai sosial (Social Value), lingkungan masyarakat (Civil Society), inovasi (Innovation) dan kegiatan ekonomi (Economic Activity) (Muliadi, 2012:2).

1) Social Value : Ini merupakan elemen paling khas dari kewirausahaan sosial yakni menciptakan manfaat sosial yang nyata bagi masyarakat dan lingkungan sekitar.

2) Civil Society : Kewirausahaan sosial pada umumnya berasal dari inisiatif dan partisipas masyarakat sipil dengan mengoptimalkan modal sosial yang sudah ada di masyarakat.

3) Innovation : kewirausahaan sosial memecahkan masalah sosial dengan cara-cara inovatif antara lain dengan memadukan kearifan lokal dan inovasi sosial.

4) Economic Activity: Kewirausaan Sosial yang berhasil pada umumnya dengan menyeimbangkan antara aktivitas sosial dan aktivitas bisnis.

Kewirausahaan Sosial biasanya digunakan untuk menjelaskan semua progam ekonomi yang melayani misi sosial dan atau misi lingkungan hidup. Kewirausahaan sosial ini lebih fokus pada pencapaian efisiensi ekonomi dan inovasi sosial, yang terjadi dalam konteks ketidak menentuan yang sangat besar terhadap masa depan.I 


\section{Karakteristik Kewirausahaan Sosial}

Menurut Purnomo (2020:51), kewirausahaan memiliki beberapa karakteristik sebagai berikut:

1) Kesediaan untuk berkorban dan cepat bertindak. Pengorbanan bukan hanya menyangkut harta benda, melainkan juga menyediakan waktu, tenaga dan pikiran.

2) Kesediaan untuk memulai berkarya secara diam-diam, sebab biasanya mereka mulai bekerja di area yang tidak dikenal orang.

3) Seperti halnya wirausahawan bisnis, mereka harus mau bekerja dengan energi penuh serta, melakukan banyak hal sekaligus.

4) Para wirausahawan sosial memiliki kecerdasan yang luar biasa dalam mengambil jarak untuk melihat "beyond the orthodoxy" dalam bidang pekerjaan mereka.

5) Kesediaan berbagi keberhasilan. Artinya, ia tidak menganggab kesuksesan kegiatan wirausaha sosial semata-mata sebagai karya atau jerih payahnya sendiri.

\section{ISI DAN PEMBAHASAN}

\section{Peranan Perguruan Tinggi Bagi Peningkatan Kepedulian Sosial Mahasiswa Melalui Pelatihan}

\section{Kewirausahaan Sosial}

Perguruan tinggi melalui tridharma perguruan tinggi memiliki peranan penting dalam mencetak generasi penerus yang memiliki keilmuan, keahlian, karakter yang kuat, kreatif, inovatif, dan tentunya memiliki peranan positif di masyarakat.

Meluluskan sarjana bukan hanya soal menghasilkan lulusan yang nantinya akan menjalani profesi tertentu, tetapi juga menyiapkan generasi yang mampu punya peranan. Profesi bisa saja berubah atau pun untuk lapangan pekerjaan tertentu, sebuah profesi bisa saja menghilang. Namun, tidak begitu dengan peranan. Peranan seseorang membuat dia tidak bisa tergantikan oleh sistem, karena peranan ini bisa terwujud jika diikuti oleh aksi nyata.

Para mahasiswa maupun lulusan perguruan tinggi saat ini sedang menghadapi era penuh perubahan, sehingga tidakdapat diprediksi tentang apa yang akan terjadi. Karena itu para mahasiswa tidak bisa dipaksa akan menjalani profesi apa di masa depan. Mereka butuh ruang untuk mengeksplorasi dan meningkatkan kapasitas diri. Salah satunya melalui pelatihan kewirausahaan.

Saat ini ada beberapa perguruan tinggi yang mulai tertarik dengan kewirausahaan sosial, seperti Universitas Padjajaran yang mendirikan komunitas wirausaha sosial di bawah naungan kampus yang diberi nama The Local Enablers. The Local Enablers merupakan wadah persemaian, penumbuhan, pemantapan, akselerasi, serta pengembangan berkelanjutan wirausaha 
melalui proses inovasi sosial (Purnomo,2020:66). Pembangun sebuah bisnis sosial dengan model bisnis yang utuh butuh proses panjang. Bisnis sosial ini dibangun dengan visi sosial untuk memberikan dampak positif bagi masyarakat.

Dengan mengembangkan bisnis sosial sama artinya dengan mengembangkan bisnis yang dekat dengan masyarakat, karena diharapkan keberadaan bisnis sosial ini bisa menjadi solusi permasalahan yang ada di masyarakat. Bisnis sosial tentunya berbeda dengan bisnis konvensional. Jika bisnis konvensional berorientasi pada ekonomi dan finansial tetapi pada bisnis sosial juga dipertimbangkan dampak yang bisa diberikan.

Visi sosial yang dimiliki oleh bisnis ini menjadi landasan untuk membangun proses bisnisnya. Pendekatan bisnis sosial ini biasanya erat kaitannya dengan rantai manfaat yang disesuaikan dengan triple bottom line yang menyeimbangkan unsur-unsur masyarakat (people), keuntungan (profit), dan lingkungan (environment). Untuk bisa menyeimbangkan tiga unsur ini, mahasiswa harus peka terhadap kondisi di sekitarnya.

Dalam proses penyeimbangan ketiga unsur di atas, mahasiswa akan berfokus pada bagaimana memberikan solusi nyata atas permasalahan-permasalahan sosial yang ada untuk menciptakan value dan mengantarkannya pada konsumen dan penerima manfaat.

Peningkatan kepedulian sosial mahasiswa erat kaitannya dengan dampak yang diberikan. Perguruan tinggi diharapkan mampu menghasilkan impact entrepreneur yang mampu memiliki peranan dalam menyelesaikan permasalahan di masyarakat.

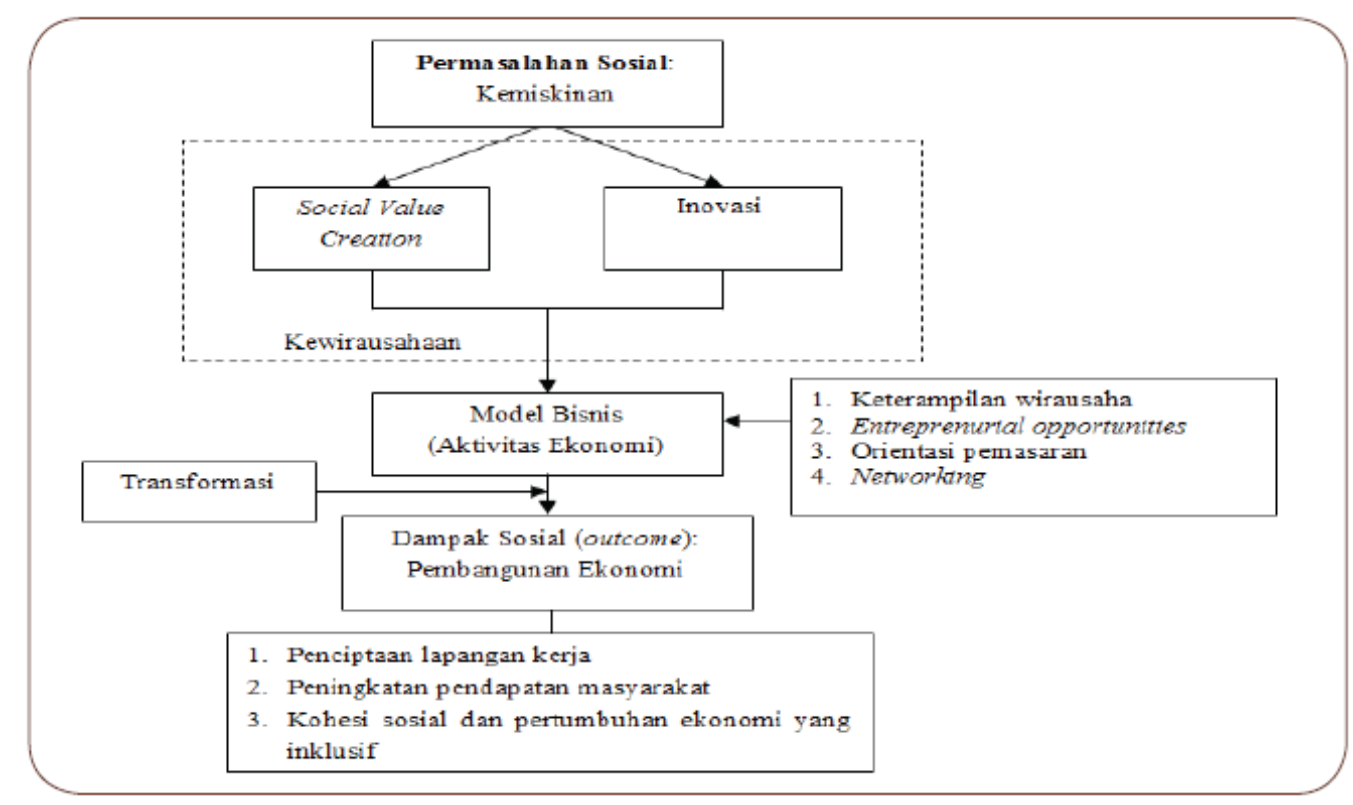

Gambar 1 Proses Kewirausahaan Sosial (Nur Firdaus,2004 : 34) 
Untuk mewujudkan cita-cita menghasilkan lulusan yang memiliki kepedulian sosial, perguruan mengadakan pelatihan-pelatihan kewirausahaan dengan tujuan tidak hanya menghasilkan wirausahawan, tetapi juga melatih mahasiswa untuk menata mindset bahwa mereka adalah generasi muda yang memiliki peran positif di masyarakat, agent of change, dan pembentukan karakter yang kreatif, inovatif, dan memiliki daya juang.

\section{Hal-hal Yang Bisa Diajarkan Dalam Pelatihan Kewirausahaan Sosial}

\section{A. Triple Bottom Line}

Dalam pelatihan usaha berbasis sosial, perlu diajarkan mengenai model usaha yang memiliki dampak sosial. Pemahaman yang mendalam mengenai hal-hal ini berfokus pada tiga hal, yaitu : faktor sosial, lingkungan, dan budaya. Hal ini dapat mempengaruhi cara usaha berbasis sosial dijalankan.

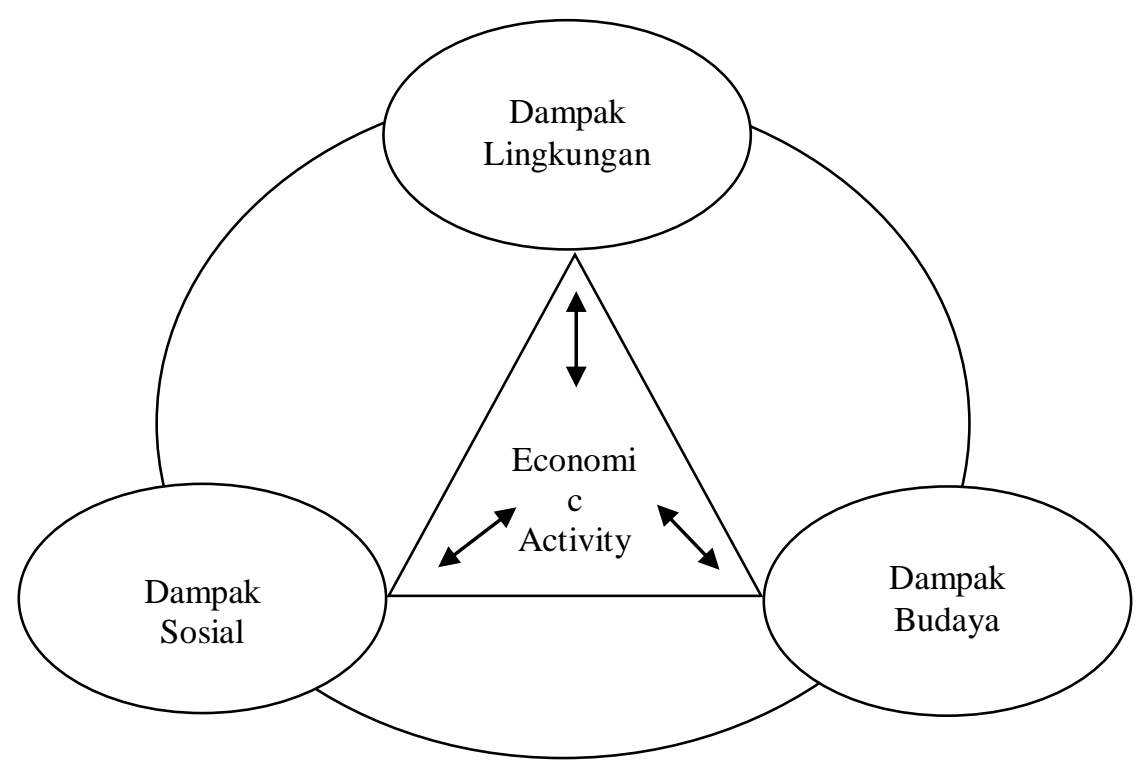

Gambar 2 Triple Bottom Line

Dengan bisa mengetahui pentingnya ketiga hal ini bersinergi, diharapkan mahasiswa mampu mengasah kemampuan analisanya supaya bisnisnya tetap bisa berjalan dan membawa dampak positif bagi masyarakat. Di sinilah peranan perguruan tinggi diperlukan. Dengan mengadakan pelatihan kewirausahaan, diharapkan mampu memberikan wadah belajar supaya mahasiswa-mahasiswa mampu berlatih mengenali potensi dari bisnis yang akan atau sedang dijalankan. 


\section{B. Mengenali Potensi Diri Sendiri}

Selain mengenali permasalahan yang ada di masyarakat sekitarnya, melalui pelatihan kewirausahaan mahasiswa juga diajarkan untuk mengenali potensi diri sendiri. Hal ini penting karena merekalah yang memiliki peran utama dalam menjalankan bisnisnya.

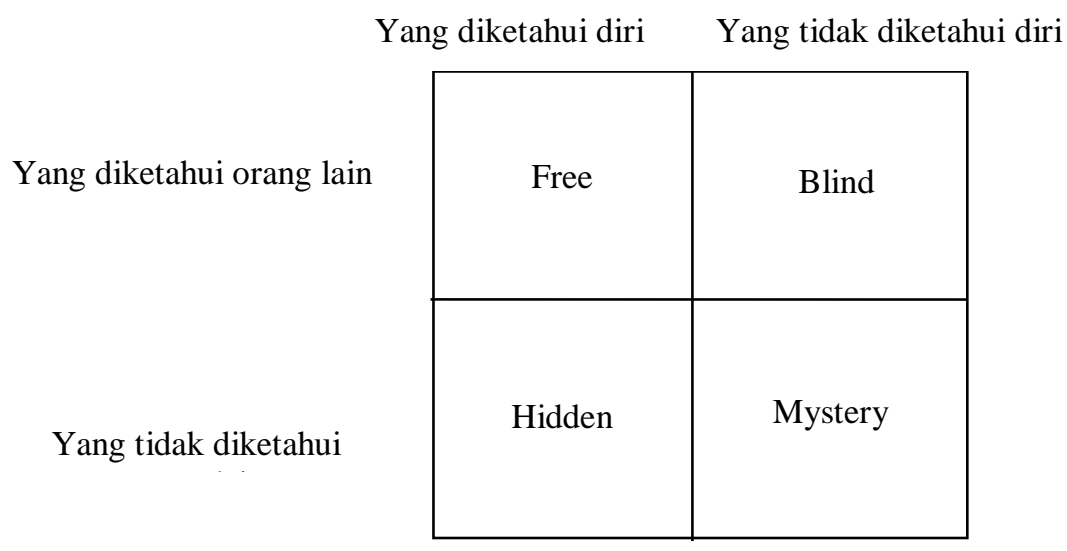

Gambar 3 Mengenali Potensi Diri

Tidak setiap orang mampu mengenali dirinya dengan baik. Ada hal-hal dalam diri seseorang yang dikenali olehnya, juga dikenali oleh orang lain. Ada bagian dalam diri seseorang yang tidak dikenali oleh orang tersebut, tetapi dikenali oleh orang lain. Ada bagian yang dikenali oleh diri sendiri, tetapi tidak dikenali oleh orang lain. Dan juga ada bagian dalam diri seseorang yang tidak mampu dia kenali dan juga tidak dikenali oleh orang lain.

Dengan mengetahui potensi ini,seseorang diharapkan mampu mengetahui potensi serta mengenali kekurangan yang dimiliki sehingga bisa dijadikan pertimbangan dalam pengembangan bisnisnya.

\section{USP (Unique Selling Propotition)}

Unique selling propotition merupakan cara mengomunikasikan usaha berbasis sosial dengan cara mempresentasikan ide usahanya secara sederhana. Melalui pelatihan kewirausahaam, mahasiswa dilatih untuk lebih luwes dalam mempresentasikan bisnisnya, salah satunya dengan berlatih elevator pitch. Elevator pitch merupakan teknik presentasi singkat, biasanya 1-3 menit, untuk memperkenalkan produk/jasanya pada calon investor.

\section{Pemetaan Masyarakat (Community Asset Mapping)}

Melalui materi ini mahasiswa diharapkan mampu mengidentifikasi tantangan, kekuatan, dan aset yang ada di dalam masyarakat, karena masyarakat memiliki aset yang 
unik untuk membangun masa depan - 'jika masalah berada di dalam masyarakat, solusinya juga berada di dalam masyarakat'.

\section{E. Model Bisnis Sosial}

Dalam pelaksanaan kegiatan social entrepreneurship harus didukung oleh model bisnis yang masuk yang baik akal dan realistis. Dalam konteks ini para pengusaha sosial dapat menggunakan ide dalam menciptakan model bisnis baru guna meningkatkan kinerja para pengusaha sosial. Selain itu perusahaan sosial harus dibangun dalam bentuk sebuah jaringan yang terkoneksi dan memilki keterpaduan dengan pengetahuan mengenai bisnis yang dapat menemukan nilai baik secara individual maupun bersamasama sebagai sebuah ekosistem.

Dalam perkembangannya, terdapat berbagai desain model bisnis social entrepreneurship yang dapat diterapkan oleh para pengusaha sosial. Terkait metode bisnis, wirausaha sosial menciptakan organisasi campuran (hybrid) yang menggunakan metodemetode bisnis, namun hasil akhirnya adalah penciptaan nilai sosial (Winarto, 2008) dalam Irma Paramita Sofia (2015: 67).

Dalam pendekatannya, dalam pelatihan bisa menggunakan Bisnis Model Kanvas (Business Model Canvas) maupun Komunitas Kanvas (Community Canvas). Bisnis model ini bisa membantu mahasiswa memetakan langkah yang akan diambil, karena dalam bisnis model kanvas bisa diketahu mengenai sasaran, pola kerjasama, strategi yang digunakan baik untuk dalam bisnis itu sendiri maupun hubungan keluar, serta potensi pendapatan bisnis.

\section{Potensi Mahasiswa dan Peluang Bisnis Sosial}

Bisnis sosial adalah sebuah konsep usaha yang memiliki visi sosial yang dijalankan menggunakan prinsip-prinsip bisnis etis, profesional, dan dilakukan dengan mempertimbangkan keberlanjutan. Usaha ini diarahkan untuk menghasilkan profit agar mampu mandiri dan tidak bergantung pada pihak lain dalam melakukan visi sosialnya (Purnomo, 2020:52).

Mengajarkan bisnis sosial berarti mengajarkan pada mahasiswa untuk mengasah kepekaan, berpikir kritis, dan bisa merumuskan strategi untuk memberikan solusi bagi permasalahan di sekitarnya. Wirausaha sosial memiliki tantangan yang cukup besar karena disamping menjalankan bisnis yang menghasilkan profit, juga haru mampu berperan dalam penyelasaian permasalahan di sekitarnya.

Mahasiswa sebagai generasi muda, generasi yang memliki rasa keingintahuan lebih dan memiliki potensi besar untuk bisa mengembangkan diri merupakan aktor penting dalam perkembangan kewirausahaan di masyarakat. Keberadaan mahasiswa ini sudah mewarnai laju 
perekonomian yang ada saat ini. Mereka bisa mengambil peranan melalui bisnis sosial yang dijalankan.

Dalam pelatihan kewirausahaan sosial, mahasiswa-mahasiswa ini dididik untuk menumbuhkan rasa peduli, mengaplikasikan ilmu, dan memberikan sebnyak mungkin manfaat untuk masyarakat (Purnomo, 2020:56). Mereka berproses dan bertumbuh menjadi generasi yang berdaya. Peran yang diambil bisa berupa menjadi pegiat desa yang mendukung

Potensi mahasiswa sebagai generasi muda ini cukup besar karena pada kurun 2020 - 2030 Indonesia akan mengalami bonus demografi dimana $60 \%$ - 70\% penduduknya yang merupakan generasi milenial dan generasi $\mathrm{Z}$ berada di usia produktif. Jika para pemuda ini dilatih untuk mengelola wirausaha sosial, mereka akan mampu berperan sebagai pendorong laju perekonomian dan membawa perubahan besar dalam pembangunan di masyarakat.

Untuk mewujudkan cita-cita ini, perguruan tinggi mengadakan pelatihan kewirausahaan dengan bekerjasama denga berbagai stakeholder yang kompeten di bidang kewirausahaan. Proses panjang perjalanan pelatihan ini merupakan proses kreatif yang akan lebih mudah dilaksanakan jika ada kolaborasi. Kolaborasi ini bisa lintas keilmuan, lintas sektor, ditunjang riset, dan bergabung dengan komunitas-komunitas wirausaha yang ada di masyarakat. Dengan begitu, proses dan tingkat keberhasilannya akan lebih tinggi.

Keberadaan pelatihan kewirausahaan serta perguruan tinggi sebagai support system, akan memunculkan iklim belajar yang baik untuk mahasiswa. Ada banyak perubahan baik yang bisa didapatkan. Tidak hanya pola pikir, tetapi perilakunya pun berubah. Para mahasiswa akan memiliki tingkat kepedulian di atas rata-rata, semangat berbaginya tinggi, dan memiliki mental yang tangguh. Mereka akan tumbuh sebagai pribadi yang memiliki empati tinggi, mengutamakan proses, menghargai orang lain, peduli, dan solutif.

Ada 6 tahapan penting yang dilalui oleh seorang wirausahawan sosial, yaitu : aksi, nilai/value, momentum, pivot, keberlanjutan, dan replikasi. Keenam hal ini tertuang dalam podel proses pengembangan dalam pelatihan kewirausahaan yang dapat dilihat pada gambar berikut: 


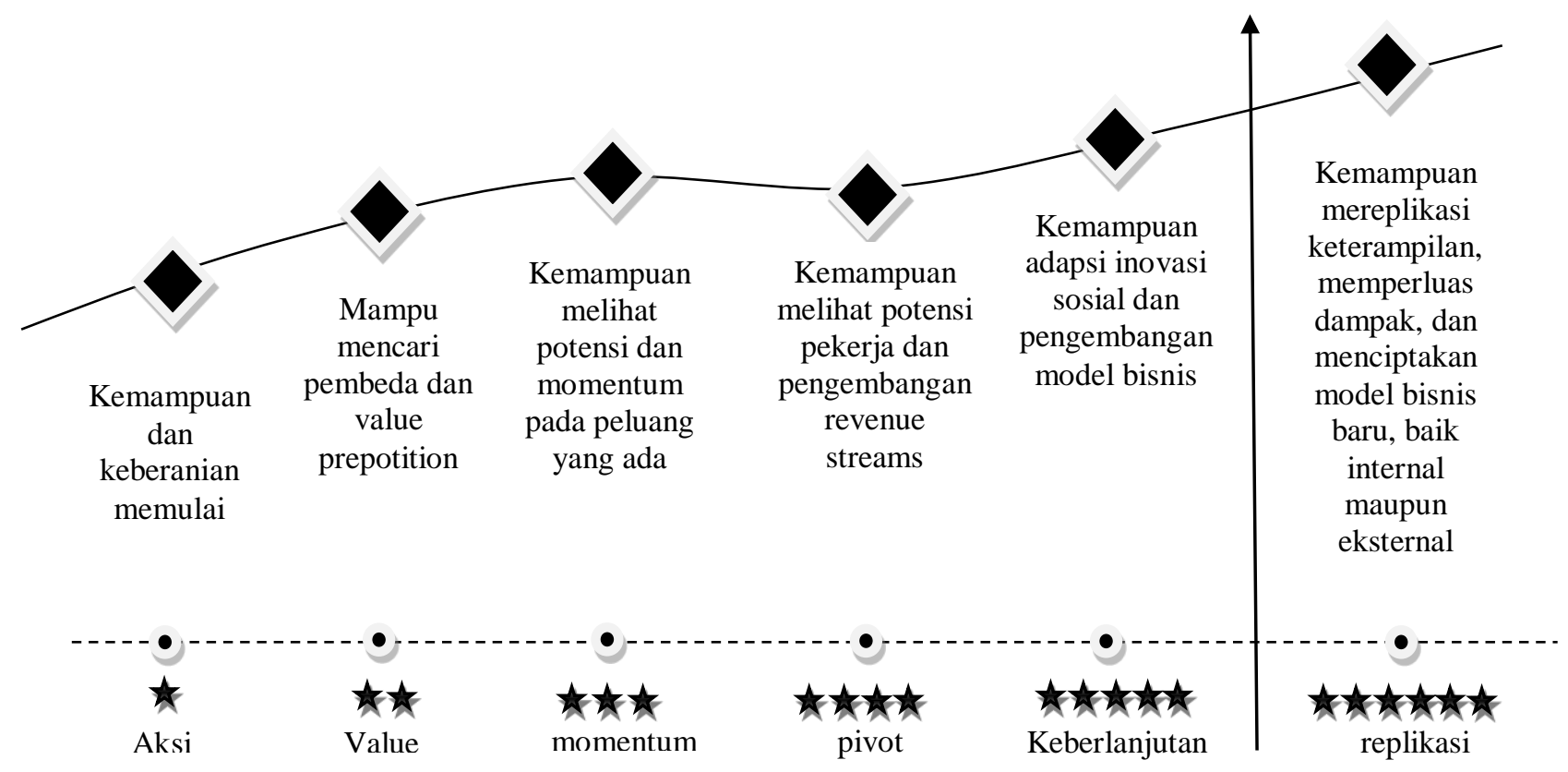

Gambar 4 Model Proses Pengembangan

Dengan mengikuti pelatihan kewirausahaan diharapkan mahasiswa bisa memiliki keberanian memulai usaha, mampu mencari pembeda dan value prepotition dari bisnisnya, melihat potensi, mengadopsi inovasi, dan pada akhirnya bisa mereplikasi keterampilan untuk diajarkan pada orangorang di sekitarnya sehingga bisa menebar manfaat untuk lebih banyak orang lainnya.

\section{PENUTUP}

\section{Kesimpulan}

Perguruan tinggi sebagai wadah belajar bagi mahasiswa memiliki peranan besar dalam membentuk sumber daya manusia mahasiswanya supaya menjadi pribadi yang tangguh. Mereka akan tumbuh sebagai pribadi yang memiliki empati tinggi, mengutamakan proses, menghargai orang lain, peduli, dan solutif. Oleh karena itu, perguruan tinggi bisa melakukan peningkatan kapabilitas mahasiswnya melalui pelatihan-pelatihan, salah satunya pelatihan kewirausahaan sosial.

Dalam kewirausahaan sosial, mahasiswa akan belajar tentang bisnis sosial yang dekat dengan masyarakat. Diharapkan dengan mengembangkan bisnis sosial ini bisa menjadi solusi permasalahan yang ada di masyarakat. Pendekatan bisnis sosial ini biasanya erat kaitannya dengan rantai manfaat yang disesuaikan dengan triple bottom line yang menyeimbangkan unsur-unsur masyarakat (people), keuntungan (profil), dan lingkungan (planet). Untuk bisa menyeimbangkan tiga unsur ini, mahasiswa harus peka terhadap kondisi di sekitarnya.

Peningkatan kepedulian sosial mahasiswa erat kaitannya dengan dampak yang diberikan. Perguruan tinggi diharapkan mampu menghasilkan impact entrepreneur yang mampu memiliki peranan dalam menyelesaikan permasalahan di masyarakat. Dengan mengikuti pelatihan kewirausahaan diharapkan mahasiswa bisa memiliki keberanian memulai usaha, mampu mencari 
pembeda dan value prepotition dari bisnisnya, melihat potensi, mengadopsi inovasi, dan pada akhirnya bisa mereplikasi keterampilan untuk diajarkan pada orang-orang di sekitarnya sehingga bisa menebar manfaat untuk lebih banyak orang lainnya

\section{Saran}

Dalam pengadaan pelatihan, perguruan tinggi hendaknya bekerjasama dengan berbagai pihak lintas sektor, dimana latar belakang yang berbeda akan memperkaya pemahaman serta pengalaman mahasiswa. Pelatihan kewirausahaan ini sebaiknya dilaksanakan secara berkelanjutan supaya bisa terbentuk ekosistem penjunjang kewirausahaan yang mampu menjadi pendorong serta mendukung mahasiswa merintis bisnis sosialnya.

\section{DAFTAR RUJUKAN}

Dacin, M. T., Dacin, P. A., \& Tracey, P. (2011). Social entrepreneurship: A critique and future directions. Organization Science, 22(5), 1203-1213.doi:10.1287/orsc.1100.0620

Nur Firdaus 2014 .Jurnal Ekonomi Dan Pembangunan. Pengentasan Kemiskinan Melalui Pendekatan Kewirausahaan Sosial. Peneliti Pusat Penelitian Ekonomi Lembaga Ilmu Pengetahuan Indonesia. Vol 22, No. 1.

Palesangi, Muliadi (2012). Pemuda indonesia dan kewirausahaan sosial. Prosiding Seminas Competitive Advantage , 1(2)

Purnomo, Dwi. 2017. Entrepreneur Speak Up. Bandung. Bitread Publishing

Purnomo, Dwi. 2020a. Jangan Lelah Berproses. Bandung. Serambi Publishing

Purnomo, Dwi. 2020b. 99 Vitamin. Bandung. Bitread Publishing

Sofia, Paramita. 2015. Konstruksi Model Kewirausahaan Sosial (Social Entrepreneurship) sebagai gagasan inovasi sosial bagi pembangunan perekonomian. Jurnal Widyakala: Universitas Pembangunan Jaya. Vol 2

Taufik, \& Siti Nurjanah. (2019). Upaya Pembentukan Karakter Pada Siswa Kelas V Melalui Pendidikan Keagamaan Di Mi Salafiyah 02 Tasikmadu Tahun Pelajaran 2017/2018. Tadris : Jurnal Penelitian Dan Pemikiran Pendidikan Islam, 12(2), 101-119. 